\title{
Growth in fossil and extant deer and implications for body size and life history evolution
}

Christian Kolb ${ }^{1 *}$, Torsten M Scheyer ${ }^{1}$, Adrian M Lister ${ }^{2}$, Concepcion Azorit ${ }^{3}$, John de Vos ${ }^{4}$, Margaretha AJ Schlingemann ${ }^{5}$, Gertrud E Rössner ${ }^{6}$, Nigel T Monaghan ${ }^{7}$ and Marcelo R Sánchez-Villagra ${ }^{1}$

\begin{abstract}
Background: Body size variation within clades of mammals is widespread, but the developmental and life-history mechanisms by which this variation is achieved are poorly understood, especially in extinct forms. An illustrative case study is that of the dwarfed morphotypes of Candiacervus from the Pleistocene of Crete versus the giant deer Megaloceros giganteus, both in a clade together with Dama dama among extant species. Histological analyses of long bones and teeth in a phylogenetic context have been shown to provide reliable estimates of growth and life history patterns in extant and extinct mammals.

Results: Similarity of bone tissue types across the eight species examined indicates a comparable mode of growth in deer, with long bones mainly possessing primary plexiform fibrolamellar bone. Low absolute growth rates characterize dwarf Candiacervus sp. II and C. ropalophorus compared to Megaloceros giganteus displaying high rates, whereas Dama dama is characterized by intermediate to low growth rates. The lowest recorded rates are those of the Miocene small stem cervid Procervulus praelucidus. Skeletal maturity estimates indicate late attainment in sampled Candiacervus and Procervulus praelucidus. Tooth cementum analysis of first molars of two senile Megaloceros giganteus specimens revealed ages of 16 and 19 years whereas two old dwarf Candiacervus specimens gave ages of 12 and 18 years.
\end{abstract}

Conclusions: There is a rich histological record of growth across deer species recorded in long bones and teeth, which can be used to understand ontogenetic patterns within species and phylogenetic ones across species. Growth rates sensu Sander \& Tückmantel plotted against the anteroposterior bone diameter as a proxy for body mass indicate three groups: one with high growth rates including Megaloceros, Cervus, Alces, and Dama; an intermediate group with Capreolus and Muntiacus; and a group showing low growth rates, including dwarf Candiacervus and Procervulus. Dwarf Candiacervus, in an allometric context, show an extended lifespan compared to other deer of similar body size such as Mazama which has a maximum longevity of 12 years in the wild. Comparison with other clades of mammals reveals that changes in size and life history in evolution have occurred in parallel, with various modes of skeletal tissue modification.

Keywords: Island evolution, Pleistocene, Cervidae, Candiacervus, Megaloceros, Bone histology, Cementum analysis, Growth rates, Longevity, Skeletal maturity

\section{Background}

Several lineages of mammals have evolved remarkable changes in body size following island isolation [1-3], including among others dwarf hippopotamuses, elephants, and deer, and giant rabbits [4-6]. These patterns are the result of complex interplay of multiple variables, including resource limitation and ecological release [5,7-9]. To

\footnotetext{
* Correspondence: christian.kolb@pim.uzh.ch

${ }^{1}$ Paläontologisches Institut und Museum der Universität Zürich, Karl

Schmid-Strasse 4, CH-8006 Zürich, Switzerland

Full list of author information is available at the end of the article
}

understand the mechanisms of life-history and size evolution on islands but also in cases of significant body size changes in mainland lineages, histology of hard tissues is a powerful tool, as has been demonstrated for 'dwarf' and 'giant' sauropod [10-12] and tyrannosaurid [13] dinosaurs, as well as early synapsids $[14,15]$ among fossil forms.

A remarkable example of island evolution is found in the Pleistocene of Crete, where an endemic clade of deer, Candiacervus, including 'dwarfed' species, evolved from the megacerine clade (Megacerini) of larger forms [16-19]. 
Despite of the unresolved nature of megacerine phylogeny [20], the small Candiacervus morphotypes must have undergone size reduction since all their postulated mainland sister-groups are significantly larger (e.g. Praemegaceros spp. with shoulder heights ranging from $0.9 \mathrm{~m}$ to $1.50 \mathrm{~m}[18,19]$ or Cervus peloponnesiacus with a shoulder height of just slightly less than one metre [21]. The kind of dwarfism we observe in Candiacervus has been described as autapomorphic nanism by [22]. Candiacervus shows diversity in size, as six size classes of deer have been distinguished $[16,17]$. The smallest morphotype, C. ropalophorus, reached a shoulder height of about $40 \mathrm{~cm}, C$. sp. II one of about $60 \mathrm{~cm}$, and the largest one reached a height of about $1.65 \mathrm{~m}$ [23]. This phenomenon has been interpreted as a case of adaptive radiation [24]. In the Middle to Late Pleistocene, Crete was characterized by dense forest as well as jagged rocks with several intermediate kinds of environments, in which such a radiation could have occurred [5]. Here we study Candiacervus ropalophorus and C. sp. II, as these two size classes are small and are represented by growth series we could sample. 'Candiacervus sp. II' may be a composite of three morphotypes of similar size [17].

Representing the other extreme of size with a shoulder height of up to $2 \mathrm{~m}$ [20], Megaloceros giganteus has been a subject of extensive debates on evolutionary processes $[20,25,26]$. It is best known from fossil occurrences in Ireland from 11 to $12,000 \mathrm{BP}$ [27] years ago and from possessing the largest antlers of any fossil or living species. Megaloceros was widespread in Europe and western Asia for 400,000 years and morphological and molecular analyses have supported a close relationship with fallow deer, Dama dama [20,28] (Figure 1a). The fossil record of deer is long and complex, and Procervulus praelucidus from the Early Miocene of Germany represents a stem taxon that can help to reconstruct the evolution of life history features in deer [29] (Figure 1a).

In order to enhance reproductive success life history traits can be selected by adjusting the developmental schedule to match environmental conditions [36]. Bone microstructure can reveal such traits in mammals, which generally exhibit bone matrices indicative of high rates of tissue deposition in juveniles, whereas after onset of maturity a decrease in bone growth rate occurs resulting in deposition of highly organized bone tissue [37-39]. Lines of arrested growth (LAGs) form from the first year of an individual's postnatal life as a result of annual cessation of bone growth [40,41]. Counting these LAGs therefore provides the means to estimate minimum individual ages [40]. However, there can be decoupling of the number of LAGs in long bones and the actual age of old individuals leading to underestimation of individual ages [42]. Dental cementum is a more accurate source for estimating longevity in mammals, due to its usual absence of resorption [43] and more complete growth record, as shown by studies on growth marks in living species, including deer of known age [43,44]. For example, using cementum analysis in molars, $99 \%$ of a sample of 51 Spanish red deer could be aged within a one year confidence interval [45].

Palaeohistology previously led to the discovery in the island goat Myotragus balearicus from the Late Pleistocene of the Balearic Islands, of a 'reptile'-like growth pattern consisting of lamellar-zonal bone throughout the cortex [46]. Myotragus was therefore hypothesized to have grown at low but variable rates and to have ceased its growth cyclically. Our investigation of Candiacervus and of relevant mainland cervids, focusing on bone microstructure in growth series of various long bones, and dental histology in old adults, serves to examine whether the pattern of growth of Myotragus is general among island artiodactyls. Longevity estimates, based on the rest lines in the first molar of old individuals, were made. The first molar is the first permanent tooth to erupt [45], showing the most complete growth record in deer. In order to further examine growth patterns across cervids and to put life history data attained by histological analyses into an allometric context, we investigated the relation between body weight and growth rates [47-49].

\section{Methods}

A total of 51 long bones, six phalanges, four lower first molars and two upper first molars of Candiacervus sp. II and Candiacervus ropalophorus, 14 long bones and five lower first molars of Megaloceros giganteus, and 13 long bones and 2 lower first molars of Procervulus praelucidus were sampled (Table 1, see also Additional file 1: Methods). Sixteen long bones and two lower first molars of Dama dama, and one femur each of Muntiacus muntjak, Cervus elaphus and Alces alces, were sampled for comparison. Of Capreolus capreolus one femur and one metacarpal were sampled. Following standard procedures, the bones were coated and impregnated with epoxy resin (Araldite or Technovit) prior to sawing and grinding. Long bones were transversely sectioned at mid-shaft where the growth record is most complete [e.g. 10]. For cementum analysis jaws were longitudinally cut through the cementum interroot pad of the lower first molar and surfaces were impregnated with epoxy resin and finally ground and polished. Long bones of Megaloceros giganteus were also sampled by using a diamond-studded core drill, with sampled cores being subsequently processed [10,50]. Sections were observed in normal transmitted and crosspolarized light using a Leica DM $2500 \mathrm{M}$ composite microscope equipped with Leica DFC $420 \mathrm{C}$ digital camera. Since there are no remarkable differences in the bone tissue of the two Candiacervus morphotypes 


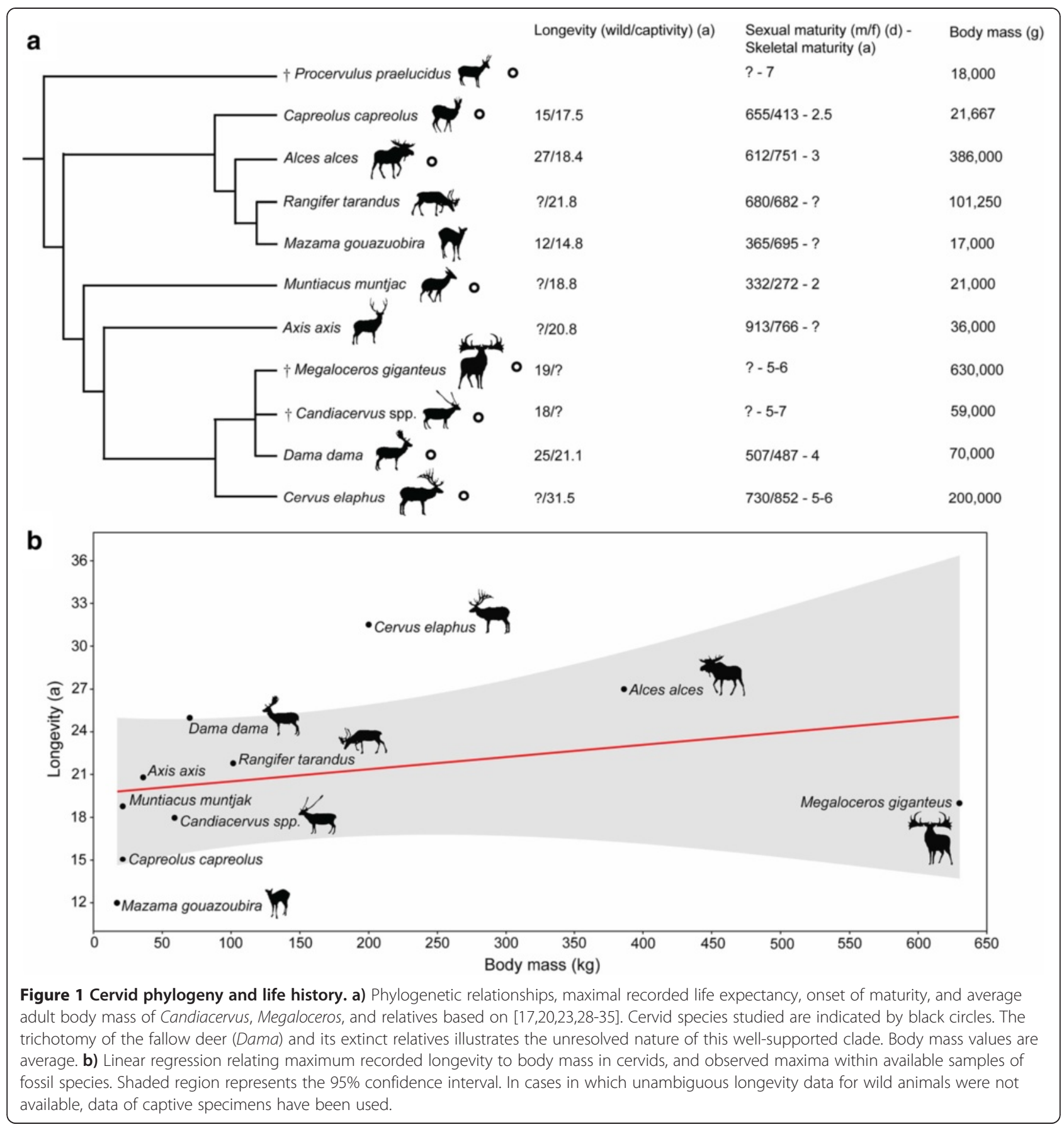

sampled, they are treated together here. Polished tooth surfaces were observed using a Leica MZ 165 and MZ 125 reflected-light microscope.

For quantification of growth rates, distances between LAGs, i.e. growth zones were measured with Leica IM 50 Image Manager ${ }^{\circ}$, and annual growth rates per day were calculated [51] by dividing growth zones by the number of days per growth period and year. The estimate of number of days per growth period, i.e. 260 days, is based on [41]. Growth period intervals (275-245 days)
[41] and a 365 day growth period have been taken into account as well (Additional file 2). Since growth zone thickness may vary considerably within the cortex of one bone, all measurements have been performed along the anteroposterior axis in the anterior quadrant of each section, whereas micrographs presented in this work have been taken from the best preserved and histologically most informative areas. Growth zone measurements were performed for femora and tibiae since they are the most informative long bones in cervids 
Table 1 Material used in this study

\begin{tabular}{|c|c|c|c|c|}
\hline Species & Object & Ontogenetic stage & Locality & Specimen number \\
\hline Candiacervus ropalophorus & Femur & adult & Gerani 4, Crete (Greece) & PIMUZ AN 5195 \\
\hline$"$ & $"$ & adult & $"$ & PIMUZ AN 5202 \\
\hline$"$ & $"$ & perinatal & $"$ & PIMUZ AN 5207 \\
\hline$"$ & $"$ & perinatal & $"$ & PIMUZ AN 5206 \\
\hline$"$ & Tibia & adult & $"$ & PIMUZ AN 5188 \\
\hline$"$ & $"$ & adult & $"$ & PIMUZ AN 5189 \\
\hline$"$ & $"$ & juvenile & $"$ & PIMUZ AN 5208 \\
\hline$"$ & $"$ & juvenile & $"$ & PIMUZ AN 5193 \\
\hline$"$ & $"$ & perinatal & $"$ & PIMUZ AN 5191 \\
\hline$"$ & $"$ & perinatal & $"$ & PIMUZ AN 5194 \\
\hline$"$ & Metatarsus & adult & $"$ & PIMUZ AN 5192 \\
\hline$"$ & $"$ & juvenile & $"$ & PIMUZ AN 5254 \\
\hline$"$ & $"$ & perinatal & $"$ & PIMUZ AN 5205 \\
\hline$"$ & Humerus & adult & $"$ & PIMUZ AN 5190 \\
\hline$"$ & $"$ & perinatal & $"$ & PIMUZ AN 5187 \\
\hline$"$ & $"$ & perinatal & $"$ & PIMUZ AN 5203 \\
\hline$"$ & Radius & adult & $"$ & PIMUZ AN 5186 \\
\hline$"$ & $"$ & adult & $"$ & PIMUZ AN 5199 \\
\hline$"$ & $"$ & perinatal & $"$ & PIMUZ AN 5200 \\
\hline$"$ & Ulna & perinatal & $"$ & PIMUZ AN 5255 \\
\hline$"$ & Metacarpus & adult & $"$ & PIMUZ AN 5197 \\
\hline$"$ & $"$ & juvenile & $"$ & PIMUZ AN 5198 \\
\hline$"$ & Lower M1 & adult & $"$ & PIMUZ AN 5196 \\
\hline Candiacervus sp. II & Femur & adult & Liko, Crete (Greece) & PIMUZ AN 5218 \\
\hline$"$ & $"$ & juvenile & $"$ & PIMUZ AN 5219 \\
\hline$"$ & $"$ & perinatal & $"$ & PIMUZ AN 5244 \\
\hline$"$ & $"$ & perinatal & $"$ & PIMUZ AN 5245 \\
\hline$"$ & Tibia & adult & $"$ & PIMUZ AN 5222 \\
\hline$"$ & $"$ & juvenile & $"$ & PIMUZ AN 5220 \\
\hline$"$ & $"$ & perinatal & $"$ & PIMUZ AN 5221 \\
\hline$"$ & $"$ & perinatal & $"$ & PIMUZ AN 5234 \\
\hline$"$ & Metatarsus & adult & $"$ & PIMUZ AN 5240 \\
\hline " & $"$ & adult & $"$ & PIMUZ AN 5212 \\
\hline$"$ & $"$ & juvenile & $"$ & PIMUZ AN 5213 \\
\hline$"$ & $"$ & juvenile & $"$ & PIMUZ AN 5223 \\
\hline$"$ & $"$ & perinatal & $"$ & PIMUZ AN 5224 \\
\hline$"$ & Humerus & adult & $"$ & PIMUZ AN 5231 \\
\hline$"$ & $"$ & juvenile & $"$ & PIMUZ AN 5236 \\
\hline$"$ & $"$ & perinatal & $"$ & PIMUZ AN 5237 \\
\hline$"$ & Radius & adult & $"$ & PIMUZ AN 5232 \\
\hline$"$ & $"$ & adult & $"$ & PIMUZ AN 5233 \\
\hline$"$ & $"$ & juvenile & $"$ & PIMUZ AN 5230 \\
\hline$"$ & $"$ & perinatal & $"$ & PIMUZ AN 5211 \\
\hline$"$ & $"$ & perinatal & $"$ & PIMUZ AN 5257 \\
\hline
\end{tabular}


Table 1 Material used in this study (Continued)

\begin{tabular}{|c|c|c|c|c|}
\hline$"$ & $"$ & perinatal & $"$ & PIMUZ AN 5214 \\
\hline$"$ & Ulna & adult & $"$ & PIMUZ AN 5215 \\
\hline$"$ & $"$ & juvenile & $"$ & PIMUZ AN 5225 \\
\hline$"$ & $"$ & perinatal & $"$ & PIMUZ AN 5226 \\
\hline$"$ & Metacarpus & adult & $"$ & PIMUZ AN 5246 \\
\hline$"$ & $"$ & juvenile & $"$ & PIMUZ AN 5247 \\
\hline$"$ & $"$ & perinatal & $"$ & PIMUZ AN 5209 \\
\hline$"$ & $"$ & perinatal & $"$ & PIMUZ AN 5210 \\
\hline$"$ & 1st Phalange & adult & $"$ & PIMUZ AN 5238 \\
\hline$"$ & $"$ & juvenile & $"$ & PIMUZ AN 5239 \\
\hline$"$ & $"$ & perinatal & $"$ & PIMUZ AN 5216 \\
\hline$"$ & 2nd Phalange & adult & $"$ & PIMUZ AN 5217 \\
\hline$"$ & $"$ & juvenile & $"$ & PIMUZ AN 5235 \\
\hline$"$ & $"$ & perinatal & $"$ & PIMUZ AN 5227 \\
\hline$"$ & Rib & adult & $"$ & PIMUZ AN 5228 \\
\hline$"$ & Lower M1 & adult & $"$ & PIMUZ AN 5229 \\
\hline$"$ & $"$ & adult & $"$ & PIMUZ AN 5243 \\
\hline$"$ & Upper M1 & senescent (18 years) & $"$ & PIMUZ AN 5241 \\
\hline$"$ & $"$ & adult & $"$ & PIMUZ AN 5242 \\
\hline Candiacervus sp. & Lower M1 & senescent (12 years) & Bate cave, Crete (Greece) & PV M 82318 (NHML) \\
\hline Procervulus praelucidus & Femur & adult & Wintershof-West, Germany & BSPG 1937 || 23226 \\
\hline$"$ & $"$ & adult & $"$ & BSPG 1937 || 23227 \\
\hline$"$ & $"$ & juvenile & $"$ & BSPG 1937 || 23228 \\
\hline$"$ & $"$ & juvenile & $"$ & BSPG 1937 || 23229 \\
\hline$"$ & Tibia & adult & $"$ & BSPG 1937 || 23230 \\
\hline$"$ & $"$ & adult & $"$ & BSPG 1937 || 23231 \\
\hline$"$ & $"$ & juvenile & $"$ & BSPG 1937 || 23232 \\
\hline$"$ & Humerus & adult & $"$ & BSPG 1937 || 23233 \\
\hline$"$ & $"$ & adult & $"$ & BSPG 1937 || 23234 \\
\hline$"$ & Radius & adult & $"$ & BSPG 1937 || 23235 \\
\hline$"$ & $"$ & adult & $"$ & BSPG 1937 || 23236 \\
\hline$"$ & $"$ & adult & $"$ & BSPG 1937 || 23237 \\
\hline$"$ & $"$ & adult & $"$ & BSPG 1937 || 23238 \\
\hline$"$ & Lower M1 & adult & $"$ & BSPG 1937 || 12002 \\
\hline$"$ & $"$ & adult & $"$ & BSPG 1937 || 12040 \\
\hline Megaloceros giganteus & Femur & adult & Craddanstown Rep. of Ireland & NMING:F7937/4 \\
\hline$"$ & $"$ & adult & Baunmore Townland, Rep. of Ireland & NMING:F21306/13 \\
\hline$"$ & Tibia & adult & Ballyragget, Rep. of Ireland & NMING:F22655/34 \\
\hline$"$ & $"$ & adult & Buttevant, Rep. of Ireland & NMING:F22534/5 \\
\hline$"$ & $"$ & adult & Baunmore Townland, Rep. of Ireland & NMING:F21306/14 \\
\hline$"$ & Metatarsus & adult & North Sea sediments & PIMUZ AN 5256 \\
\hline$"$ & $"$ & adult & Baunmore Townland, Rep. of Ireland & NMING:F21306/19 \\
\hline$"$ & $"$ & adult & Buttevant, Rep. of Ireland & NMING:F22534/6 \\
\hline$"$ & Humerus & adult & Ballyragget, Rep. of Ireland & NMING:F22655/37 \\
\hline$"$ & $"$ & adult & Buttevant, Rep. of Ireland & NMING:F22534/2 \\
\hline
\end{tabular}


Table 1 Material used in this study (Continued)

\begin{tabular}{|c|c|c|c|c|}
\hline$"$ & Radius-Ulna & adult & Ballyragget, Rep. of Ireland & NMING:F22655/36 \\
\hline$"$ & $"$ & adult & Buttevant, Rep. of Ireland & NMING:F22534/3 \\
\hline$"$ & Metacarpus & adult & Ballyragget, Rep. of Ireland & NMING:F22655/31 \\
\hline$"$ & $"$ & adult & Buttevant, Rep. of Ireland & NMING:F22534/4 \\
\hline$"$ & Lower M1 & senescent (19 years) & Brühl (Schwetzingen), Deutschland & PIMUZ AN 2235 \\
\hline$"$ & $"$ & senescent (16 years) & Kent'scavern, Torquay, UK & PV OR 16800 (NHML) \\
\hline$"$ & $"$ & senescent (n.a.) & Wyhlen, Germany & BSPG 1957 | 398 \\
\hline$"$ & $"$ & adult & Rath, Rep. of Ireland & NMING:F22654 \\
\hline$"$ & $"$ & adult & Craddanstown, Rep. of Ireland & NMING:F7937/5 \\
\hline Dama dama & Femur & adult (wild) & Schrevenborn, Germany & ZIUK 9630 \\
\hline$"$ & $"$ & adult (captive) & Wildnispark Zürich, Switzerland & PIMUZ AN 5248 \\
\hline$"$ & $"$ & adult (captive) & $"$ & PIMUZ AN 5248 \\
\hline$"$ & $"$ & juvenile (captive) & $"$ & PIMUZ AN 5249 \\
\hline$"$ & Tibia & adult (wild) & Schrevenborn, Germany & ZIUK 9630 \\
\hline$"$ & $"$ & adult(captive) & WildnisparkZürich, Switzerland & PIMUZ AN 5248 \\
\hline$"$ & $"$ & adult (captive) & $"$ & PIMUZ AN 5248 \\
\hline$"$ & $"$ & juvenile (captive) & $"$ & PIMUZ AN 5249 \\
\hline$"$ & Humerus & adult (wild) & Schrevenborn, Germany & ZIUK 9630 \\
\hline$"$ & $"$ & adult (captive) & Wildnispark Zürich, Switzerland & PIMUZ AN 5248 \\
\hline$"$ & $"$ & adult (captive) & $"$ & PIMUZ AN 5248 \\
\hline$"$ & $"$ & juvenile (captive) & $"$ & PIMUZ AN 5249 \\
\hline$"$ & Radius-Ulna & adult (wild) & Schrevenborn, Germany & ZIUK 9630 \\
\hline$"$ & $"$ & adult (captive) & Wildnispark Zürich, Switzerland & PIMUZ AN 5248 \\
\hline$"$ & $"$ & adult (captive) & $"$ & PIMUZ AN 5248 \\
\hline " & $"$ & juvenile (captive) & $"$ & PIMUZ AN 5249 \\
\hline$"$ & Lower M1 & adult (wild) & Schrevenborn, Germany & ZIUK 9630 \\
\hline$"$ & $"$ & adult (captive) & Wildnispark Zürich, Switzerland & PIMUZ AN 5248 \\
\hline Capreolus capreolus & Femur & adult (wild) & Schrevenborn, Germany & ZIUK 9872 \\
\hline$"$ & Metatarsus & juvenile (wild) & Hittnau, Switzerland & PIMUZ AN 5251 \\
\hline Muntiacus muntjak & Femur & adult (captive) & Tierpark Hagenbeck, Hamburg, Germany & ZIUK 7994 \\
\hline Cervus elaphus & $"$ & adult (wild) & Barmstedt, Germany & ZIUK 23517 \\
\hline Alces alces & $"$ & adult (wild) & Norway & ZMUZ 20242 \\
\hline
\end{tabular}

Specimens used in this study with ontogenetic stage, locality of death/fossil site, specimen number and thin section number.

Institutional Abbreviations: BSPG Bayerische Staatssammlung für Paläontologie und Geologie, Munich, Germany; NBC Netherlands Centre for Biodiversity Leiden The Netherlands; NHML Natural History Museum London, UK; NMING National Museum of Ireland - Natural History; PIMUZ Paläontologisches Institut und Museum, Universität Zürich, Switzerland; ZIUK Zoologisches Institut der Universität Kiel, Germany; ZMUZ Zoologisches Museum der Universität Zürich, Switzerland.

(see also Additional file 1: Methods). For growth rate graphs Microsoft Office Excel $2010^{\odot}$ has been used. Regression analyses (ordinary least squares) for average and growth rates sensu Sander \& Tückmantel [51] were performed using Past3.0 [52]. All graphs have been redrawn using Adobe Illustrator $\mathrm{CS} 5{ }^{\odot}$.

\section{Results and discussion}

Histological description of primary bone

Newborn dwarf Candiacervus (C. ropalophorus and $C$. sp. II) exhibit fibrolamellar bone with a high amount of woven-fibred bone as primary tissue (Figure 2a). In the inner cortex, vascularization tends to be reticular, whereas in the middle and outer cortex vascularization has a plexiform pattern. With increasing age, the amount of vascularisation and woven bone decreases, with the former changing from a plexiform to laminar organisation in the middle and outer cortex, whereas the amount of lamellar or parallel-fibred bone within the fibrolamellar matrix increases (Figure 2a-c). The outermost layer of the outer cortex in adult Candiacervus sampled is composed of a narrow layer of avascular lamellar bone, called the outer 


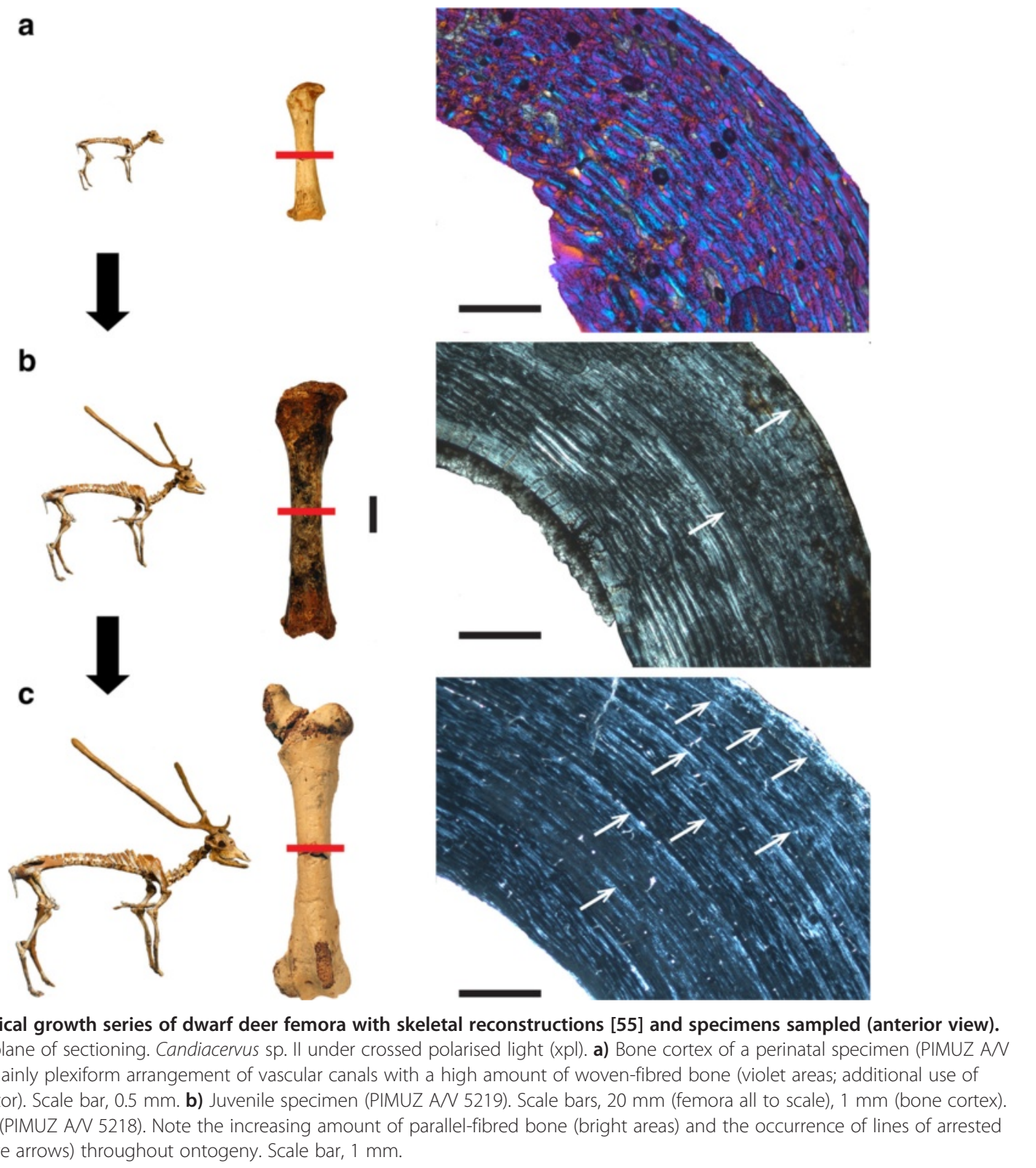

circumferential layer (OCL) [53] in this work and also referred to as external fundamental system (EFS, e.g. sensu [42], see also [54]). We prefer the term outer circumferential layer for being more descriptive than the term external fundamental system. An inner circumferential layer [38] is well developed in all adult femora. Long bones of Candiacervus indicate, based on growth line counts, minimum ages of about two years for the juveniles sampled.

Adult Megaloceros, Dama, Cervus, and Alces show in all sampled long bones a similar arrangement of bone tissue types to each other. Vascularisation in the outer part of the cortex is partly longitudinal, whereas in dwarf
Candiacervus, Procervulus, and Muntiacus it changes directly from plexiform/laminar to avascular in the outer circumferential layer. This is evidently a feature separating large and intermediate from small-sized deer, including dwarf Candiacervus. Moreover, the density of vascular canals is higher in intermediate-sized and larger deer compared to smaller taxa (Figure 3a-c, see also Additional file 1: Table S2 and Figure S1). Because it is a juvenile specimen and still shows less vascularisation than the adult Dama and Megaloceros, specimen BSPG 1937 II 23227 is especially illustrative concerning the low amount of vascularization in the small sized cervid Procervulus (Figure 3a-c). 



Figure 3 Cervid bone tissue and growth marks. Increasing femoral vascularisation (a-c) accompanied by increasing body size in a) juvenile Procervulus specimen BSPG 1937 II 23227, medial cortex (xpl; scale bar, 0.5 mm), b) adult Dama specimen ZIUK 9630, medial cortex (xpl; scale bar, $1 \mathrm{~mm}$ ), and c) adult Megaloceros specimen NMING: F21306/13 under plane polarised light, anterior cortex (ppl, scale bar $1 \mathrm{~mm}$ ). Note the low amount of vascularisation in the fibrolamellar bone of the juvenile Procervulus. Occurrence of LAGs indicated by black/white arrows and the outer circumferential layer by white brackets. Numbers indicate growth zones. Bone surfaces at the top, medullary cavities at bottom left. d) Tibia of adult Candiacervus sp. II (PIMUZ AN 5222) showing Haversian bone in the inner part of the posterior cortex (bright area) and plexiform fibrolamellar bone in the middle part (Ipl; scale bar, $1 \mathrm{~mm}$ ). Occurrence of LAGs indicated by white arrows. Bone surface at top right, medullary cavity at bottom left. e) Radiating fibrolamellar bone in a metacarpal of adult Megaloceros giganteus (NMING:F22534/4, xpl; scale bar, 0.5 mm). f) First phalange of perinatal Candiacervus sp. II (PIMUZ AN 5216) showing reticular vascularisation of mainly woven-fibred bone (xpl; scale bar, $0.2 \mathrm{~mm}$ ).

A longitudinal section of a Megaloceros femur confirms the low amount of woven-fibred bone in plexiform bone tissue [56] (Figure 4a,b). However, since woven-fibred bone is present, we follow [57] in using the term fibrolamellar bone. In general, the bone tissue found in the femora and humeri gives a similar picture. The differences in the amount of vascularisation observed in dwarf Candiacervus and large/intermediate sized cervids are less obvious in the humeri than those seen in the femora. Unlike Candiacervus (Figure 3d), tibiae of
Dama and Megaloceros show areas of radiating fibrolamellar bone interdigitating with the otherwise plexiform bone tissue. In general, adult radii of all sampled deer have a similar arrangement of bone tissue types, i.e. plexiform fibrolamellar bone with a varying amount of Haversian bone. The amount of woven bone of perinatal ulnae of dwarf Candiacervus is high in the inner cortex.

Similarity of bone tissue types in Candiacervus, Megaloceros, and Capreolus shows a comparable mode of growth in the metapodials. A remarkable difference

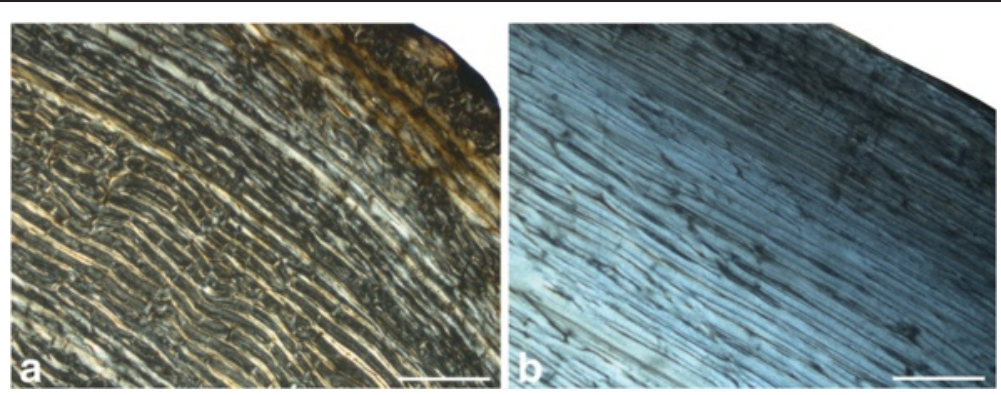

Figure 4 Bone cortex of Megaloceros giganteus. Femur (NMING: F21306/13) in transverse (a) and longitudinal (b) section under crossed polarised light (bone surface top right). Note the low amount of woven fibred bone (dark areas) in the longitudinal section. 
distinguishing adult Megaloceros from Candiacervus is the occurrence of layers of radiating fibrolamellar bone (Figure 3e) in the middle and outer cortex of Megaloceros. The inner circumferential layer is relatively thicker in Megaloceros than in Candiacervus.

Phalanges of newborn Candiacervus specimens show fibrolamellar bone with reticular vascularisation (Figure 3f). During ontogeny, the vascular organisation becomes plexiform, but with increasing age this is replaced by increasing amounts of poorly vascularised lamellar/parallel-fibred bone in the sub-periosteal region.

\section{Secondary bone and remodelling processes}

Perinatal specimens of Candiacervus show no signs of bone remodelling. In general, resorption of primary bone and deposition of secondary osteons in cervid long bones starts in juveniles (Figure 5a). Large areas of Haversian bone in adults indicate strong bone remodelling during ontogeny. Apart from the femora, which have a mainly circular outline in cross section, Haversian bone is most dense where the curvature of the cortex is greatest, but in all long bones and specimens the area most affected by remodelling is the posterior area of the cortex.

In the femora, remodelling starts in the juvenile Candiacervus specimens with scattered secondary osteons in the middle cortex, mainly in its posterior part. Adult femora of all deer species sampled show strong remodelling (i.e. Haversian bone) in the posterior part, obscuring the growth record in this area of the bone. Remodelling is strongest in the cortical area of the linea aspera.

Similar to the femora, remodelling in the humeri of juvenile specimens of Candiacervus and Dama starts in the middle zone of the medial part of the cortex (Figure 5a). Adult humeri of all deer groups sampled show more remodelling than the femora. Nevertheless, the amount of remodelling is low enough to leave a sufficient growth record.

Tibiae of juvenile Candiacervus and Dama start being remodelled mainly in the medial and lateral parts of the middle and inner cortex, leading to the deposition of dense Haversian bone (Figure 3d). In rare cases, dense Haversian bone is also found in the outermost part of the cortex in Megaloceros. Again, however, the amount of remodelling is low enough to leave a sufficient growth record.

Haversian bone in juvenile radii of Candiacervus and Dama indicates an early onset of secondary remodelling in the inner cortex. Strong remodelling in adult radii of Candiacervus, Dama, and Megaloceros, especially in the posterior area of the inner cortex, obscures the growth record to a large degree in these bones.

Ulnae of all juvenile deer species sampled are already remodelled to a high degree, especially in the inner cortex surrounding the medullary cavity, indicated by dense Haversian bone. Adult ulnae are strongly remodelled leaving only small areas of primary bone tissue in the posterior part of the cortex. During ontogeny, the medullary cavity shifts to the anterior area of the cortex being subsequently closed by the deposition of endosteal lamellar bone which is in turn subsequently replaced by dense Haversian bone (Figure 5b). Due to this strong remodelling of the ulnae in all deer species sampled, and since only small areas of primary plexiform bone tissue are left in the bone cortex, skeletochronological interpretations are not feasible.

Remodelling in metapodials begins with the development of Haversian bone in the inner cortex and is already strongly developed in juvenile specimens. In all specimens, the area most affected by remodelling is the posterior area of the cortex. Adult deer metapodials are strongly remodelled, occupying about half of the cortex and obliterating
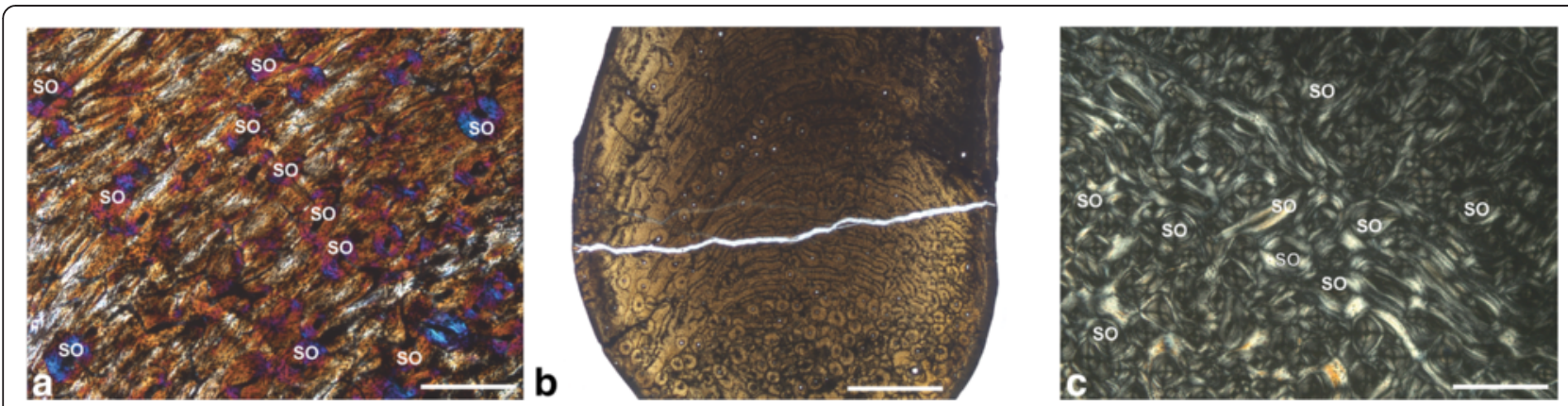

Figure 5 Cervid bone remodelling. a) Humerus of juvenile Candiacervus sp.ll specimen PIMUZ AN 5236 (xpl, lambda compensator, scale bar $0.5 \mathrm{~mm}$ ). Note the scattered secondary osteons (SO). b) UIna of adult Candiacervus sp. II specimen PIMUZ AN 5215 (Ipl, scale bar $1 \mathrm{~mm}$ ) displaying plexiform fibrolamellar bone (centre) and dense Haversian bone (bottom). Note that the medullary cavity (bottom) has been subsequently closed by the deposition of endosteal lamellar bone which was in turn replaced by secondary Haversian bone. Anterior at the bottom. c) Dense Haversian bone in a metacarpal of adult Megaloceros giganteus specimen NMING: F22534/4 (xpl, scale bar $0.5 \mathrm{~mm}$ ). 
the growth record by development of dense Haversian bone (Figure 5c).

\section{Skeletochronology and growth mark analysis}

Cyclical growth patterns have been observed in many extant artiodactyls [41]. However, in mammals bone resorption and remodelling may occur throughout ontogeny and LAG counts and age are apparently decoupled in old individuals [40,42,43]. Therefore, individual ages are often underestimated by bone histological studies, making cementum analysis a crucial tool in order to study longevity in fossil cervids (see also Additional file 1: Discussion).

LAGs are present in all deer taxa sampled. Femora, tibiae, and humeri of adult specimens show, due to relatively low remodelling, the highest LAG counts. The maximum LAG counts seen in adult femora are eight in dwarf Candiacervus ( $\mathrm{n}=3$, Figure 2c), six in Dama $(\mathrm{n}=2)$, and 10 in Megaloceros $(\mathrm{n}=2)$.

In order to quantify growth rates in the sampled deer taxa, we measured non-remodelled cortical growth zones until the "virtual end of circumferential bone growth" [42]. Growth marks in the outermost part of the bone cortex, not giving a signal because of similarity and diminutiveness of growth zone thickness, have been omitted. It has recently been shown that in antelope (Addax nasomaculatus) femora the first LAG is resorbed during ontogeny [39]. Ruminants such as antelopes and cervids show similar long bone morphology as well as similar arrangement of bone tissue types, bone remodelling, and resorption patterns [41,58]. Superimposition of sections of femora and tibiae of perinatal, juvenile, and adult dwarf Candiacervus, juvenile and adult specimens of Procervulus praelucidus, and a juvenile as well as two adult specimens of known-age Dama dama however indicate that no LAG is lost during ontogeny in femora and tibiae of these cervids. On the grounds of phylogenetic parsimony we consider it as justified to assume that in general bone resorption patterns are identical throughout cervids. This approach made retrocalculation techniques as performed for dinosaurs dispensable [12,59]. In order to make growth rate measurements comparable, we numbered the growth zones of adult specimens starting with two since the first growth zone is at least partially resorbed and not available for skeletochronology (Figure 3b,c,d).

Additionally, and in order to verify our observations made by growth zone counts and measurements, we followed [51] in determining how fast dwarf Candiacervus, Megaloceros, and Procervulus grew over a hypothetical 365 days growth period by assessing growth rates sensu Sander \& Tückmantel and comparing them to the values observed in extant cervids. Although bone growth rates per day are always approximations, they allow comparison to and verification of known bone apposition rates in extant and fossil vertebrates [51,60].

In contrast to dwarfed forms of Candiacervus and to Dama, Megaloceros femora indicate up to five times higher growth rates, with the second growth zone yielding a rate of $7.69 \mu \mathrm{m} / \mathrm{d}$, the third one $3.69 \mu \mathrm{m} / \mathrm{d}$, and growth zones four to six between $2.04-1.35 \mu \mathrm{m} / \mathrm{d}$ (Figure 6a). The femora of C. ropalophorus indicated a growth rate of $2.19 \mu \mathrm{m} / \mathrm{d}$ to $1.81 \mu \mathrm{m} / \mathrm{d}$ in growth zones two to four (Figure 6a). In the following year the growth rate slightly decreased to $1.04 \mu \mathrm{m} / \mathrm{d}$. The growth rate of Candiacervus sp. II decreased from $3.34 \mu \mathrm{m} / \mathrm{d}$ in growth zone two to $1.19 \mu \mathrm{m} / \mathrm{d}$ in growth zone four. In growth zones five to seven the growth rate ranged from $0.69 \mu \mathrm{m} / \mathrm{d}$ to $0.81 \mu \mathrm{m} / \mathrm{d}$. The femoral growth rate of Dama is higher than that of C. ropalophorus and equal to that of Candiacervus sp. II in the second growth zone $(3.34 \mu \mathrm{m} / \mathrm{d})$. After that, growth rate strongly decreased below the rates of $C$. ropalophorus and sp. II $(0.73$ and $0.84 \mu \mathrm{m} / \mathrm{d})$.

The growth rates recorded in the tibiae are similar to the ones obtained for the femora. C. ropalophorus grew in zone two at a rate of $2.47 \mu \mathrm{m} / \mathrm{d}$, whereas Candiacervus sp. II only grew at $0.69 \mu \mathrm{m} / \mathrm{d}$ (Figure 6b). D. dama, at $2.54 \mu \mathrm{m} / \mathrm{d}$, occupies an intermediate position between the dwarfed deer and Megaloceros $(5.81 \mu \mathrm{m} / \mathrm{d})$. Growth rate strongly decreases from zone two to zone three in most deer species sampled: $2.76 \mu \mathrm{m} / \mathrm{d}$ in Procervulus, $3.07 \mu \mathrm{m} / \mathrm{d}$ in Megaloceros but only $0.34 \mu \mathrm{m} / \mathrm{d}$ in C. sp. II. There is discrepancy among taxa, and C. ropalophorus, although the smallest species, shows about four times higher growth rate in the second growth zone (similar to Dama) compared to Candiacervus sp. II (Figure 6b). This demonstrates the diversity of life history parameters across morphotypes of Candiacervus in Crete during the Pleistocene [61,62].

Average growth rates of $0.46 \mu \mathrm{m} / \mathrm{d}$ (Figure 6c) in femora of Procervulus were the lowest measured for all the deer taxa sampled, lying below the lower limit of their 95\% confidence interval. Muntiacus, Capreolus, Dama and dwarf Candiacervus show average to low growth rates around $1.4 \mu \mathrm{m} / \mathrm{d}$, whereas Cervus elaphus $(2.58 \mu \mathrm{m} / \mathrm{d})$ had distinctly higher growth rates lying on the upper limit of the $95 \%$ confidence interval. Alces alces shows with $3.68 \mu \mathrm{m} / \mathrm{d}$ the highest average growth rates. In contrast, the absolute high growth rates (based on the growth zones preserved in the cortical bone tissue) of Megaloceros are relatively low given the regression (Figure 6c, average $3.23 \mu \mathrm{m} / \mathrm{d}$ ), but still within the limits of the $95 \%$ confidence interval.

Growth rates sensu Sander \& Tückmantel plotted against the anteroposterior bone diameter as a proxy for body mass indicate three groups (Figure 7): A group with high growth rates including Megaloceros $(14.22 \mu \mathrm{m} / \mathrm{d})$, Cervus elaphus (ZIUK 23517; $12.66 \mu \mathrm{m} / \mathrm{d}$ ), Alces (ZMUZ 

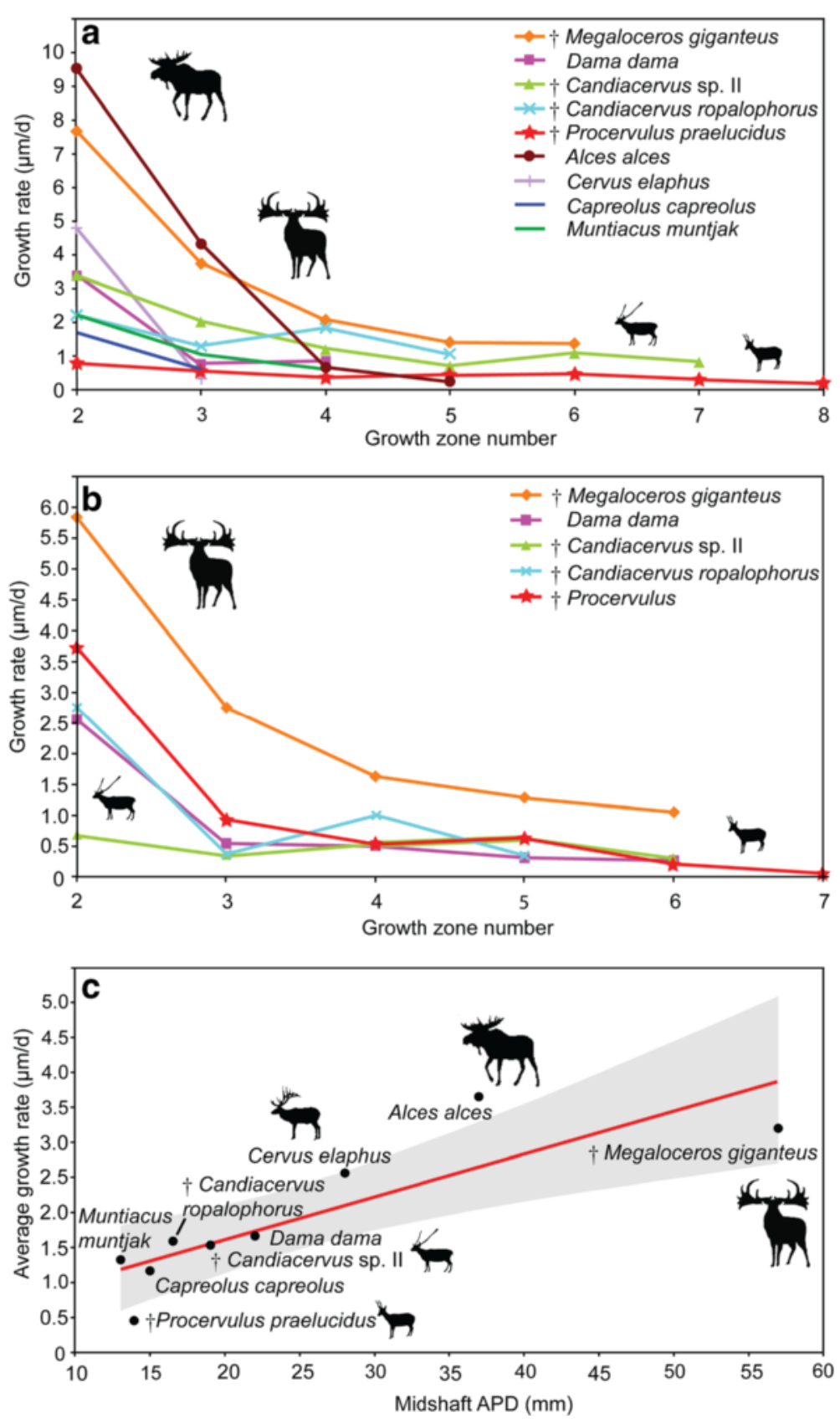

Figure 6 Cervid growth rates. a) Graph of growth zone measurements of cervid femora sampled. Points indicate sample means or measurements of single specimens (see also Additional file 2). Note exceptionally high growth rates in the first two growth zones of Alces and Megaloceros as well as exceptionally low rates of Procervulus. Growth zones numbered, starting with two for the innermost complete zone of the cortex. b) Graph of cervid tibiae sampled. Note the eight times higher growth rate in growth zone two of Megaloceros compared to Candiacervus sp. II (and still twice as high as in C. ropalophorus). c) Regression of average growth rates in cervid femora ( $n=12, r=0.85111, p=0.0036142$.). Shaded region represents the $95 \%$ confidence interval. Anteroposterior diameter (APD) of femoral midshaft region is taken as proxy for body mass.

20242; $12.58 \mu \mathrm{m} / \mathrm{d})$, and Dama $(12.35 \mu \mathrm{m} / \mathrm{d})$; an intermediate group with Capreolus (ZIUK 9872; $6.79 \mu \mathrm{m} / \mathrm{d}$ ) and Muntiacus (ZIUK 7994; $5.75 \mu \mathrm{m} / \mathrm{d}$ ); and a group showing low growth rates, including Candiacervus sp. II (PIMUZ A/V 5218, $3.7 \mu \mathrm{m} / \mathrm{d}$ ), and ranging from $4.16 \mu \mathrm{m} / \mathrm{d}$ in
Candiacervus ropalophorus to $2.6 \mu \mathrm{m} / \mathrm{d}$ in Procervulus (Figure 7). Dama and Cervus elaphus plot above the upper limit of the $95 \%$ confidence interval whereas only Candiacervus sp. II lies well below the lower limit of the $95 \%$ confidence interval. All other cervids sampled show 


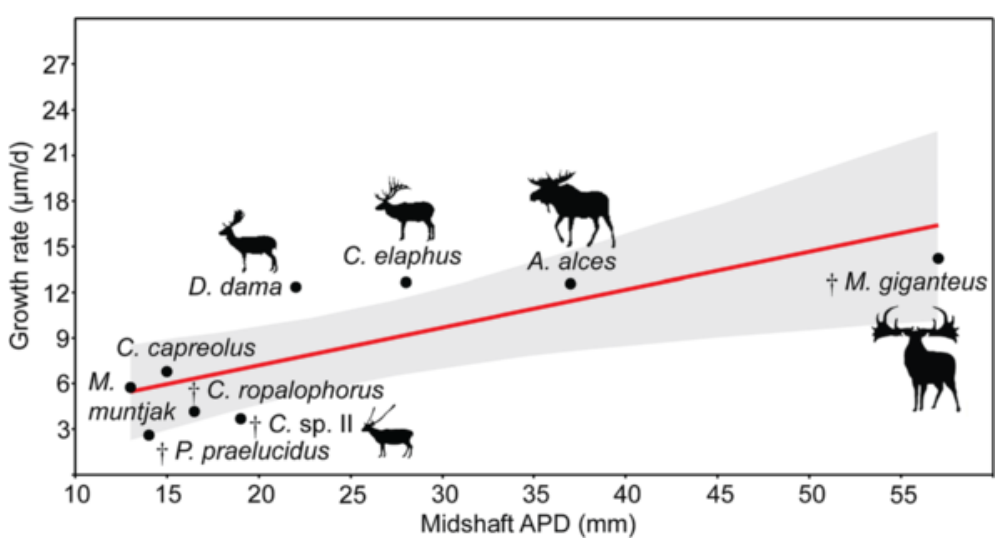

Figure 7 Regression of growth rates sensu Sander \& Tückmantel in cervid femora $(n=12, r=0.78168, p=0.012835)$. Shaded region represents the $95 \%$ confidence interval. Anteroposterior diameter (APD) of femoral midshaft region is taken as proxy for body mass (see also Additional file 2).

growth rates within the 95\% range given their body size (see also Additional file 1: Discussion).

\section{Skeletal maturity estimates}

Examination of femora of extant cervid taxa revealed the occurrence of OCLs not coeval with the timing of sexual maturity, as reported for femora of antelopes [39]. An adult specimen of Dama dama (ZIUK 9630; Figure 3b) shows three LAGs before the OCL, in contrast to the onset of sexual maturity which has been reported to occur during the second year of life in Dama dama [63] (Figure 1a). These observations suggest that the transition of the fibrolamellar complex (FLC) to the OCL, which is not clearly definable in every specimen, is indicating cervid skeletal maturity sensu [64] and not sexual maturity. This is well in accordance with known data of skeletal maturity for Dama [30,31], and a recent study on growth marks in the bone tissue of ruminants that examined cervid bone histology in detail [41]. The bone cortex of dwarf Candiacervus femora indicates skeletal maturity at five to seven years whereas Megaloceros reached skeletal maturity at five to six years. One Procervulus specimen indicates attainment of skeletal maturity at seven years whereas Cervus elaphus (four to six years) ranges with its timing of skeletal maturity between Megaloceros and Alces (three years) [31].

\section{Cementum analysis and longevity}

Tooth cementum analysis of first molars of Candiacervus provided an age of four years for a juvenile Candiacervus sp. II and an age of at least nine years for an adult specimen of $C$. ropalophorus. Two senile Megaloceros giganteus specimens revealed ages of 16 and 19 years (Figure 8a,b). Rest lines in two old Candiacervus specimens gave ages of 12 (dwarf Candiacervus sp.) and 18 years (Candiacervus sp. II, Figure 8c). Dwarf Candiacervus thus, in an allometric context, show an extended lifespan compared to other deer of similar body size such as Mazama with a maximum longevity of 12 years in the wild (Figure 1a). This is well in accordance with observations of a recent study on population structure and dynamics in dwarf Candiacervus [62].

A positive linear relationship between body mass and longevity has been demonstrated in bats and mammals in general $[47,65]$, although this is difficult to assess in our cervid data set (Figure 1b) because of issues of comparability: for example, the 32-year maximum age of a captive specimen of Cervus elaphus [63], a farmed and extensively studied species, is probably anomalously high. Conversely, Megaloceros appears short-lived when body mass is taken into account (Figure 1b), although the sample size was small. Clearly, there is much diversity in life history across deer species, and examination of other populations of Megaloceros may reveal more diversity in the giant deer than we have recorded in our study $[18,19]$.

\section{Conclusions}

Our histological observations indicate lower growth rates in dwarf Candiacervus than in Megaloceros. The presence of laminar bone tissue in the middle and outer cortex of adults of small-sized deer (dwarf Candiacervus, Procervulus and Muntiacus) suggests lower growth rates, in contrast to the occurrence of plexiform bone in intermediate to large sized forms. Growth rates determined by growth zone measurements in femora and tibiae indicate comparable growth rates of intermediate sized and small deer species, with slower growth in the stem group cervid Procervulus. Growth rates in the two small Candiacervus morphotypes are different, underscoring the flexibility of growth strategies and the importance of a resolved phylogenetic framework to study heterochrony. Skeletal maturity data suggest late maturation for dwarf Candiacerus and Procervulus in comparison to a similarly 




Figure 8 Cervid tooth histology. a) Senescent Megaloceros specimen PIMUZ AN 2235. Left mandible in lateral view. Black bar indicates plane of sectioning. Scale bar, $50 \mathrm{~mm}$. b) Tooth cementum of same specimen showing 19 rest lines (white arrows). Scale bar, $0.5 \mathrm{~mm}$. c) Tooth cementum of the upper first molar of Candiacervus sp. II (PIMUZ AN 5241) showing 18 rest lines (black arrows). CDJ = Cementum-dentine junction. Scale bar, $0.5 \mathrm{~mm}$. Direction of cementum apposition to the bottom.

small cervid such as Muntiacus attaining skeletal maturity in two years [32].

The landmasses of islands have been hypothesized of being able to support only a limited number of primary producers affecting the energy flow at higher trophic levels. As a consequence, energy-poor islands are expected to be impoverished in competitors and predators making especially high growth rates and high reproductive rates dispensable to unnecessary [32,46,66-68]. A delay in the attainment of maturity was recorded for the dwarfed island bovid Myotragus balearicus [46], and was thought to be associated with synchronisation of metabolic requirements to fluctuating resource levels. The delay of attainment of maturity in the island cervid Candiacervus and the continental Procervulus demonstrates the variability of life history parameters in island as well as continental cervids. This might point towards fluctuating resource levels in the Late Pleistocene Crete, selecting for a growth pattern recalling that of the stem-cervid Procervulus.

The oldest individual seen in our cementum analysis of Megaloceros was 19 years, comparable to maximum longevity in extant Dama. This find extends an age based on cementum analysis [25] by five years and lies below another estimate [69] also based on cementum analysis, by four years. However, [69] did not illustrate cementum rest lines of the specimen studied. We therefore consider the result of our cementum analysis as the highest rest line count in Megaloceros. The oldest individual seen in our cementum analysis of Candiacervus was 18 years, indicating prolonged longevity for a deer of this body size.

The exact persistence time of the Candiacervus radiation on Crete is not known but was apparently much shorter, i.e., less than 0.5 myrs [5], compared to Myotragus balearicus, which dwelt on Majorca for 5.2 myrs [46]. The less extreme modification of bone tissue observed in dwarf Candiacervus could be related to shorter persistence time and perhaps to the larger size of Crete [3,8].

In life history theory, slow-developing long-lived species are typically associated with low fecundity and rapidlydeveloping short-lived species with high fecundity [36,70]. The condition found in Candiacervus has features in common with that of Myotragus [46], but is achieved with less far reaching modification of bone tissue, as indicated by the absence of lamellar-zonal bone throughout the cortex. Neither does the Myotragus pattern occur in the pygmy mammoth, Mammuthus exilis, from Santa Rosa Island, California, whose bone cortex is characterized by laminar fibrolamellar bone [71]. Therefore we suggest variable modes of life history and size evolution among island mammals in line with [65-68,72].

\section{Availability of supporting data}

The data sets supporting the results of this article are included within the article (and its additional files).

High resolution versions of the histological figures provided in this article are available on MorphoBank [73], Project P2083 (http://www.morphobank.org/permalink/? P2083).

\section{Additional files}

Additional file 1: Includes Table S1, additional discussion on individual age estimates and growth rates, additional information on methods used in this study, additional references, and Figure S1.

Additional file 2: Primary data for growth rate analysis: Growth zone measurements, mean species growth rates, average species growth rates, bone diameter, $O C L$ thickness, and number of non-OCL lines of arrested growth (for growth rates sensu Sander \& Tückmantel).

\section{Competing interests}

The authors declare that they have no competing interests. 


\section{Authors' contributions}

CK and MRS-V designed the study and wrote the manuscript, CK, TMS, MAJS and CA collected and analysed histological data, JDV, AML, NTM, and GER provided materials and taxonomic/stratigraphical information, all authors contributed to the final interpretation and editing of the manuscript. All authors read and approved the final manuscript.

\section{Acknowledgments}

We thank Naturalis Biodiversity Center, National Museum of Ireland, Natural History, Natural History Museum London (NHML), Bayerische Staatssammlung für Paläontologie und Geologie, Wildnispark Zürich, Frank Zachos (now Naturhistorisches Museum Wien), Heiner Luttmann, Zoologisches Institut der Universität Kiel, Marianne Haffner, Zoologisches Museum der Universität Zürich, Emma Bernard (NHML) and Heinz Furrer, Paläontologisches Institut und Museum der Universität Zürich (PIMUZ) for providing specimens for histological study, Alexandra van der Geer (Naturalis Biodiversity Center, Leiden) and two anonymous reviewers for constructive and improving criticism, as well as Vladimir Blagoderov, and Tony Wighton (NHML) for technical assistance. Vivien Jaquier, Fiona Straehl, Madeleine Geiger, James Neenan, Juan Carrillo, Sarah Bolliger, Markus Hebeisen, Rosi Roth and Jérôme Gapany (all PIMUZ) are thanked for various support and discussion. This work was funded by the SNSF (3100A0-133032/1 and 31003A-149605 to MRS-V; 31003A-149506 to TMS) and the Forschungskredit of the University of Zurich (No. 8264 to CK)

\section{Author details}

${ }^{1}$ Paläontologisches Institut und Museum der Universität Zürich, Karl Schmid-Strasse 4, CH-8006 Zürich, Switzerland. ²Department of Earth Sciences, The Natural History Museum, Cromwell Road, London SW7 5BD, UK. ${ }^{3}$ Department of Animal and Vegetal Biology and Ecology, Faculty of Experimental Sciences, University of Jaén, Jaén 23071, Spain. ${ }^{4}$ Naturalis Biodiversity Center, Postbus 9517, 2300 RA Leiden, The Netherlands. ${ }^{5}$ Department of Integrative Zoology, IBL, Leiden University, Sylviusweg 72, Postbus 95052300 RA Leiden, The Netherlands. ${ }^{6}$ Bayerische Staatssammlung für Paläontologie und Geologie, Richard-Wagner-Strasse 10, D-80333 München, Germany. ${ }^{7}$ National Museum of Ireland-Natural History, Merrion Street, Dublin 2, Ireland.

Received: 22 July 2014 Accepted: 27 January 2015

Published online: 14 February 2015

\section{References}

1. Foster JB. Evolution of mammals on islands. Nature. 1964;202:234-5.

2. Lomolino MV. Body size of mammals on islands: the island rule reexamined. Am Nat. 1985;125:310-6.

3. Lomolino MV, van der Geer AA, Lyras GA, Palombo MR, Sax DF, Rozzi R. Of mice and mammoths: generality and antiquity of the island rule. J Biogeogr. 2013:40:1427-39.

4. Lister AM. Rapid dwarfing of red deer on jersey in the last interglacial. Nature. 1989:342:539-42.

5. van der Geer A, Lyras G, de Vos J, Dermitzakis M. Evolution of Island Mammals. Adaptation and Extinction of Placental Mammals on Islands. Wiley-Blackwell: Sussex; 2010

6. Quintana J, Köhler M, Moyà-Solà S. Nuragulus rex, gen. et sp. nov., an endemic insular giant rabbit from the Miocene of Minorca (Balearic Islands). J Vertebr Paleontol. 2011;31(2):231-40.

7. Palkovacs EP. Explaining adaptive shifts in body size on islands: a life history approach. Oikos. 2003;103:37-44.

8. Lomolino MV, Sax DF, Palombo MR, van der Geer A. Of mice and mammoths: evaluations of causal explanations for body size evolution in insular mammals. J Biogeogr. 2012;39:842-54.

9. Raia P, Meiri S. The island rule in large mammals: paleontology meets ecology. Evolution. 2006;60:1731-42.

10. Sander PM, Andrassy P. Lines of arrested growth and long bone histology in Pleistocene large mammals from Germany: what do they tell us about dinosaur physiology? Palaeontogr Abt A. 2006;277:143-59.

11. Sander PM, Christian A, Clauss M, Fechner R, Gee CT, Griebeler E-M, et al. Biology of the sauropod dinosaurs: the evolution of gigantism. Biol Rev. 2011;86(1):117-55

12. Erickson GM, Curry Rogers $K$, Yerby SA. Dinosaurian growth patterns and rapid avian growth rates. Nature. 2001;412:429-33.
13. Erickson GM, Makovicky PJ, Currie PJ, Norell MA, Yerby SA, Brochu CA. Gigantism and comparative life history parameters of tyrannosaurid dinosaurs. Nature. 2004;430:772-5

14. Chinsamy-Turan A (ed.): Forerunners of Mammals:Rradiation, Histology, Biology. Indiana: Indiana University Press;2012.

15. Huttenlocker AK, Botha-Brink J. Bone microstructure and the evolution of growth patterns in Permo-Triassic therocephalians (Amniota, Therapsida) of South Africa. PeerJ. 2014:2:e325.

16. de Vos J. The endemic Pleistocene deer of Crete. P K Ned Akad B. 1979:82(1):59-90.

17. de Vos J. The Endemic Pleistocene Deer of Crete, vol. 31. Amsterdam: North-Holland Publishing Company; 1984.

18. Vislobokova IA. Giant deer: origin, evolution, role in the biosphere. Paleontol J. 2012;46(7):643-775

19. Vislobokova IA. Morphology, taxonomy, and phylogeny of megacerines (Megacerini, Cervidae, Artiodactyla). Palaeontol J. 2013:47(8):833-950.

20. Lister AM, Edwards CJ, Nock DAW, Bunce M, van Pijlen IA, Bradley DG, et al. The phylogenetic position of the 'giant deer' Megaloceros giganteus. Nature. 2005;438(7069):850-3.

21. Sickenberg O. Eine Säugetierfauna des tieferen Biharium aus dem Becken von Megalopolis (Peloponnes, Griechenland). Annales Géologiques des Pays Helléniques. 1975;27:25-73.

22. Gould GC, MacFadden BJ. Gigantism, dwarfism, and Cope's rule: "Nothing in evolution makes sense without a phylogeny". B Am Mus Nat Hist. 2004;285:219-37.

23. de Vos J. Pleistocene deer fauna in Crete: its adaptive radiation and extinction. Tropics. 2000;10(1):125-34.

24. de Vos J, Van der Geer A. Major patterns and processes in biodiversity: taxonomic diversity on islands explained in terms of sympatric speciation. In: WW H, EJ A, editors. World Islands in Prehistory, International Insular Investigations, V Deia International Conference of Prehistory. Oxford: British Archaeological Reports International Series; 2002. p. 395-405.

25. Chritz KL, Dyke GJ, Zazzo A, Lister AM, Monaghan NT, Sigwart JD. Palaeobiology of an extinct Ice Age mammal: Stable isotope and cementum analysis of giant deer teeth. Palaeogeogr Palaeocl. 2009;282(1-4):133-44.

26. Gould SJ. Positive allometry in antlers of the "Irish Elk", Megaloceros giganteus. Nature. 1973;244:375-6.

27. Woodman PC, McCarthy M, Monaghan NT. The Irish Quaternary fauna project. Quaternary Sci Rev. 1997;16:129-59.

28. Hughes S, Hayden TJ, Douady CJ, Tougard C, Germonpré M, Stuart A, et al. Molecular phylogeny of the extinct giant deer, Megaloceros giganteus. Mol Phylogenet Evol. 2006;40:285-91.

29. Rössner GE. Odontologische und schädelanatomische Untersuchungen an Procervulus (Cervidae, Mammalia). Münchner Geowissenschaftliche Abhandlungen (A). 1995:29:1-128.

30. McElligott AG, Mattiangeli V, Mattiello S, Verga M, Reynolds CA, Hayden TJ. Fighting tactics of fallow bucks (Dama dama, Cervidae): Reducing the risks of serious conflict. Ethology. 1998;104:789-803.

31. Habermehl K-H. Altersbestimmung bei Wild- und Pelztieren - Möglichkeiten und Methoden - Ein praktischer Leitfaden für Jäger, Biologen und Tierärzte. Verlag Paul Parey: Hamburg, Berlin; 1985.

32. Pei K. Post-natal growth of the Formosan Reeves' Muntjac Muntiacus reevesi micrurus. Zool Stud. 1996:35:111-7.

33. Palombo MR, Köhler M, Moya-Sola S, Giovinazzo C. Brain versus body mass in endemic ruminant artiodactyls: a case studied of Myotragus balearicus and smallest Candiacervus species from Mediterranean Islands. Quatern Int. 2008;182:160-83.

34. Gilbert C, Ropique A, Hassanin A. Mitochondrial and nuclear phylogenies of Cervidae (Mammalia, Ruminantia): Systematics, morphology, and biogeography. Mol Phylogenet Evol. 2006:40:101-17.

35. Hassanin A, Delsuc F, Ropiquet A, Hammer C, van Vuuren BJ, Matthee C, et al. Pattern and timing of diversification of Cetartiodactyla (Mammalia, Laurasiatheria), as revealed by a comprehensive analysis of mitochondrial genomes. C R Biol. 2012;335:32-50.

36. Stearns SC. The Evolution of Life Histories. Oxford: Oxford University Press; 1992

37. Garcia-Martinez R, Marin-Moratalla N, Jordana X, Köhler M. The ontogeny of bone growth in two species of dormice: reconstructing life history traits. C R Palevol. 2011;10(5-6):489-98. 
38. Chinsamy-Turan A. Microstructure of bones and teeth of nonmammalian therapsids. In Forerunners of Mammals: Radiation, Histology, Biology. Edited by Chinsamy-Turan A. Indiana: Indiana University Press; 2012;65-88.

39. Marin-Moratalla N, Jordana X, Köhler M. Bone histology as an approach to providing data on certain key life history traits in mammals: implications for conservation biology. Mamm Biol. 2013;78:422-9.

40. Castanet J, Croci S, Aujard F, Perret M, Cubo J, de Margerie E. Lines of arrested growth in bone and age estimation in a small primate: Microcebus murinus. J Zool. 2004;263:31-9.

41. Köhler M, Marín-Moratalla N, Jordana X, Aanes R. Seasonal bone growth and physiology in endotherms shed light on dinosaur physiology. Nature. 2012;487:358-61.

42. Woodward HN, Padian K, Lee AH. Skeletochronology. In Histology of Fossil Tetrapods - Advancing Methods, Analysis and Interpretation. Edited by Padian K, Lamm E-T. Berkeley, Los Angeles, London: University of California Press; 2013: 195-215

43. Klevezal GA. Recording Structures of Mammals. Determination of Age and Reconstruction of Life History. A.A.Balkema: Rotterdam/Brookfield; 1996.

44. Azorit C, Munoz-Cobo J, Hervas J, Analla M. Aging through growth marks in teeth of Spanish red deer. Wildl Soc Bull. 2004;32(3):702-10.

45. Azorit C, Analla M, Hervas J, Carrasco R, Munoz-Cobo J. Growth marks observation: preferential techniques and teeth for ageing of Spanish red deer (Cervus elaphus hispanicus). Anat Histol Embryol-J Vet Med Ser C. 2002;31(5):303-7.

46. Köhler M, Moyà-Solà S. Physiological and life history strategies of a fossil large mammal in a resource-limited environment. P Natl Acad Sci USA. 2009;106(48):20354-8.

47. Calder WA. Size, Function, and Life History. Cambridge, Massachusetts, London: Harvard University Press; 1984.

48. Case TJ. On the evolution and adaptive significance of postnatal growth rates in the terrestrial vertebrates. Q Rev Biol. 1978;53(3):243-82.

49. Schmidt-Nielsen K. Scaling: Why is Animal Size so Important? Cambridge \& New York: Cambridge University Press; 1984.

50. Stein K, Sander M. Histological core drilling: a less destrcutive method for studying bone histology. In: Methods in Fossil Preparation: Proceedings of the First Annual Fossil Preparation and Collections Symposium. Petrified Forest: Petrified Forest National Park; 2009. p. 69-80.

51. Sander PM, Tückmantel C. Bone lamina thickness, bone apposition rates, and age estimates in sauropod humeri and femora. Palaeontol Z. 2003;77(1):161-72.

52. Hammer $\varnothing$, Harper DAT, Ryan PD. PAST: Paleontological statistics software package for education and data analysis. Palaeontologia Electronica 2001;4(1): 9. http://palaeoelectronica.org/2001_1/past/issue1_01.htm

53. Ponton F, Elzanowski A, Castanet J, Chinsamy-Turan A, Margerie E, de Ricqlès $A$, et al. Variation of the outer circumferential layer in the limb bones of birds. Acta Ornithol. 2004:39(2):21-4.

54. Horner JR, Ricqlès AJD, Padian K. Variation in dinosaur skeletochronology indicators: implications for age assessment and physiology. Paleobiology. 1999:25:295-304

55. van der Geer A, de Vos J, Lyras G, Dermitzakis M. New data on the Pleistocene Cretan deer Candiacervus sp. II (Cervinae, Mammalia). Cour Forsch Senck. 2006:256:131-7.

56. Stein K, Prondvai E. Rethinking the nature of fibrolamellar bone: an integrative biological revision of sauropod plexiform bone formation. Biol Rev. 2013;1-24

57. Francillon-Vieillot H, de Buffrénil V, Castanet J, Géraudie J, Meunier FJ, Sire $J Y$, et al. Microstructure and mineralization of vertebrate skeletal tissues. In Skeletal Biomineralization: Patterns, Processes and Evolutionary Trends. Edited by Carter JG. New York: Van Nostrand Reinhold; 1990: 471-530

58. Enlow DH, Brown SO. A comparative histological study of fossil and recent bone tissues. Part III Tex J Sci. 1958:10:187-230

59. Horner JR, Padian K. Age and growth dynamics of Tyrannosaurus rex. P Roy Soc Lond B Bio. 2004:271:1875-80.

60. de Ricqlès A, Meunier FJ, Castanet J, Francillon-Vieillot H. Comparative microstructure of bone. In Bone Volume 3: Bone Matrix and Bone Specific Products. Edited by Hall BK. Boca Raton: CRC Press; 1991;1-78.

61. van der Geer A, Dermitzakis M, de Vos J. Relative growth of the metapodials in a juvenile island deer: Candiacervus (Mammalia, Cervidae) from the Pleistocene of Crete. Hell J Geosc. 2006:41:119-25.

62. van der Geer A, Lyras GA, MacPhee RDE, Lomolino MV, Drinia H. Mortality in a predator-free insular environment: the dwarf deer of Crete. Am Mus Novit. 2014;3807:1-26.
63. Tacutu R, Craig T, Budovsky A, Wuttke D, Lehmann G, Taranukha D, et al. Human ageing genomic resources: integrated databases and tools for the biology and genetics of ageing. Nucleic Acids Res. 2013;41(D1):D1027-33.

64. Huttenlocker AK, Woodward HN, Hall BK. The biology of bone. In Histology of Fossil Tetrapods - Advancing Methods, Analysis and Interpretation. Edited by Padian K, Lamm E-T. Berkeley, Los Angeles, London: University of California Press; 2013: 13-34.

65. Austad SN, Fischer KE. Mammalian aging, metabolism, and ecology: evidence from the bats and marsupials. J Gerontol. 1991;46(2):B47-53.

66. McNab B. Resource use and the survival of land and freshwater vertebrates on oceanic islands. Am Nat. 1994;144:643-60.

67. McNab BK. Minimizing energy expenditure facilitates vertebrate persistence on oceanic islands. Ecol Lett. 2002:5:693-704.

68. McNab BK. Geographic and temporal correlations of mammalian size reconsidered: a resource rule. Oecologia. 2010;164:13-23.

69. Aaris-Sorensen K, Liljegren R. Late Pleistocene remains of giant deer (Megaloceros giganteus Blumenbach) in Scandinavia: chronology and environment. Boreas. 2004;33:61-73.

70. Stearns SC. Life history evolution: successes, limitations, and prospects. Naturwissenschaften. 2000;87:476-86.

71. Curtin AJ, Macdowell AA, Schaible EG, Roth L. Noninvasive histological comparison of bone growth patterns among fossil and extant neonatal elephantids using synchrotron radiation X-ray microtomography. J Vertebr Paleontol. 2012:32(4):939-55.

72. Raia P, Barbera C, Conte M. The fast life of a dwarfed giant. Evol Ecol. 2003;17(3):293-312

73. O'Leary, MA; Kaufman SG. MorphoBank 3.0: Web application for morphological phylogenetics and taxonomy. 2012; http://www.morphobank.org.

\section{Submit your next manuscript to BioMed Central and take full advantage of:}

- Convenient online submission

- Thorough peer review

- No space constraints or color figure charges

- Immediate publication on acceptance

- Inclusion in PubMed, CAS, Scopus and Google Scholar

- Research which is freely available for redistribution

Submit your manuscript at www.biomedcentral.com/submit
C Biomed Central 